\title{
Credit Card Surcharges And Relative Price Differentials Across Various Market Structures
}

David Gordon, University of Saint Francis, USA

\begin{abstract}
Recent changes in federal credit card laws will lead to higher prices for consumers and heftier profits for retailers especially in monopolistic markets. This is due to the way that the surcharges are usually levied which is as a percentage of the base price of the good or service. This paper explains how prices are formed by a profit maximizing firm under the assumption of a production function that is homogeneous of degree one. This paper also demonstrates the relationship between markups and the price elasticity of demand. An analysis of how the new credit card rules would impact relative prices in markets of varying levels of competition is then performed.
\end{abstract}

Keywords: Credit Card Laws; Surcharges; Price Elasticity

\section{INTRODUCTION}

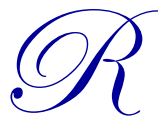

ecent changes in credit card laws have led to the distinct possibility of higher prices for consumers and heftier profits for retailers especially in markets that are less competitive. A class action lawsuit against Visa and Mastercard was recently settled at the federal level. The settlement provided for retailers to be able to impose surcharges on all transactions if they so desired. (This does not apply in states that expressly prohibit credit card surcharges such as in California, New York and Texas.) Previously these surcharges were not allowed by Visa and Mastercard. American Express and Discover has always allowed retailers to collect surcharges, but only if the surcharges were collected on all cards they accept as payment. If a retailer accepted Visa or Mastercard, as almost all do, they could then not collect surcharges on American Express or Discover credit cards. The primary reason why retailers want to collect surcharges is to offset the swipe fees charged by the credit card companies themselves. These swipe fees have increased substantially over time and now average between 1.5 and 3\% of the value of a transaction. This has run counter to debit card transaction fees which have been reduced due to the Durbin Amendment within the Dodd-Frank legislation that was recently passed.

\section{RETAILER MARKUPS UNDER PROFIT MAXIMIZATION}

It is assumed that all retailers utilizing credit cards are interested in maximizing their profits and face a constant return to scale production function. The general case is assumed where total revenue (TR) is equal to the product of the quantity of output $(\mathrm{Q})$ produced and sold and the price $(\mathrm{P})$ of the product. Total cost (TC) is assumed to be a function of the quantity of output produced. Profit $(\pi)$ is always the difference between TR and TC. In mathematical terms the profit function can be shown as:

$$
\pi=\mathrm{TR}-\mathrm{TC}=\mathrm{PQ}-\mathrm{TC}(\mathrm{Q})
$$

In order to find the profit maximizing quantity of output we need to differentiate (1) with respect to Q. This generates equation (2) below.

$$
\begin{aligned}
& \mathrm{d} \pi / \mathrm{dQ}=(\mathrm{dP} / \mathrm{dQ}) \mathrm{Q}+\mathrm{P}-(\mathrm{dTC} / \mathrm{dQ}) \quad\{\text { where } \mathrm{dTC} / \mathrm{dQ}) \text { is the marginal cost }(\mathrm{MC})\} \\
& \mathrm{P}=\mathrm{MC}-(\mathrm{dP} / \mathrm{dQ}) \mathrm{Q}
\end{aligned}
$$


We can consider the term -(dP/dQ)Q a retailer markup (m) which would be positive assuming the customary assumption about (dP/dQ) being negative.

$$
\mathrm{P}=\mathrm{MC}+\mathrm{m}
$$

Taking into consideration the assumption of constant returns to scale equation (3) can be written as (4).

$$
\mathrm{P}=\mathrm{AC}+\mathrm{m}
$$

The price elasticity of demand measures how sensitive quantity demanded is to a change in price and is shown in equation (5) as a non-negative value.

$$
\mathrm{E}=-(\mathrm{dQ} / \mathrm{dP})(\mathrm{P} / \mathrm{Q}) \geq 0
$$

This can then be presented in terms of $\mathrm{P}$ and inserted into the term for retailer markup (-(dP/dQ)Q) to arrive with equation (6).

$$
\mathrm{m}=\mathrm{P} / \mathrm{E}
$$

The major significance of (6) is that it shows an inverse relationship between $\mathrm{m}$ and $\mathrm{E}$. The more elastic the demand for the good/service the lower the potential markup by the retailer. The more inelastic the demand the higher the potential markup.

\section{PRICE ELASTICITY AND MARKET STRUCTURE}

The price elasticity of demand is a function of four variables: the number of available substitutes, the time one has to make demand decisions, the durability of a product and the proportion of total expenditures the good absorbs. The more substitutes that are available the more elastic the demand becomes. The more time one has to make a demand decision the more elastic the demand. The more durable a product the more elastic the demand. (The purchase of a durable product can be postponed for a period of time or the good can be repaired thus delaying the purchase of a replacement item.) The greater the percentage of the budget that the good takes up the more elastic the good will be.

There are four different market structures that are normally identified in economics: perfect competition (or the slightly different pure competition), monopolistic competition, oligopoly and monopoly. Perfect competition is characterized by having many sellers, homogeneous products/services, easy entry into the market (no barriers to entry) and perfect information. Each firm is a price taker under perfect competition. Monopoly is the polar opposite of perfect competition. Only one seller exist in this market. There is assumed to be no close substitutes for the good/service being sold or provided by the monopolist and there are prohibitive legal and/or economic barriers to entry that prevent any competition. Oligopolies and industries categorized as monopolistically competitive are a hybrid of perfect competition and monopoly. For purposes of this paper these two market structures will be identified collectively as imperfect competition. Prices become higher and output becomes lower as we advance from perfect competition to imperfect competition and then finally to monopolies where prices will be the highest and output the lowest of any type of market structure.

\section{RELATIVE PRICE DIFFERENTIALS}

As a market becomes more competitive three results take place. First, the more competitive a market is the more substitutes that will be available for consumers to choose from. Secondly, a higher level of competition furnishes consumers with more time to make choices, since they will not be as worried about the supply of the good running out as quickly as it might if only one firm was producing the item. Finally, competition can foster the availability of firms that repair durable goods, thus extending the life of a durable good. These three results imply the price elasticity of demand will tend to be much more elastic under perfect competition than under imperfect competition or monopoly. The ranking of price elasticity in markets from relatively more elastic to relatively more 
inelastic would be perfect competition - imperfect competition - monopoly. The markups have the following relationship:

$$
\mathrm{Mm}>\mathrm{Mo}>\mathrm{Mc}
$$

where $\mathrm{Mm}$ is the markup for a monopolist, Mo the markup under imperfect competition and Mc the markup for a perfectly competitive firm. This follows from equation (6). equations.

If we assume that each firm faces an identical cost function we generate the following base price (BP)

(1) $\mathrm{BPm}=\mathrm{AC}+\mathrm{Mm}$

(2) $\quad \mathrm{BP} 0=\mathrm{AC}+\mathrm{Mo}$

(3) $\quad \mathrm{BPc}=\mathrm{AC}+\mathrm{Mc}$

Given the information on the relative markups under each type of firm/market we have the following:

$\mathrm{BPm}>\mathrm{BPo}>\mathrm{BPc}$

Consumers would pay higher prices when markets are less competitive. This is due to the higher markups afforded by the varying demand elasticities.

The recent changes in laws governing credit cards will make this difference between competitive prices and monopolistic prices even greater. This is due to the way the credit card surcharges are applied. Each firm applies the surcharges as a percentage of the base prices. For each base price the actual price paid by consumers $(\mathrm{P})$ will be $\mathrm{BP}(1+\mathrm{i})$ where "i" is the percentage surcharge applied to the base price.

(5) $\quad \operatorname{Po}=\mathrm{BPo}(1+\mathrm{i})$

(6) $\quad \mathrm{Pc}=\mathrm{BPc}(1+\mathrm{i})$

Since the percentage surcharge is assumed to be the same regardless of market structure the nominal differences in the consumer prices will be now larger than the nominal differences in base prices. For example, Pm $\mathrm{Pc}>\mathrm{BPm}-\mathrm{BPc}$.

\section{POLICY IMPLICATIONS}

This paper demonstrates that recent changes in laws regarding credit card surcharges will increase prices in retail markets and alter relative prices among different market structures as well. The increases in prices were shown to vary depending on the level of competition within the market. In markets where less competition exist consumers will be burdened more than in more competitive markets. Consumers living in rural areas, for example, tend to be faced with less competitive markets thus they will be impacted more adversely by the recent legal changes.

\section{AUTHOR INFORMATION}

David Gordon, DBA is an assistant professor in the College of Business and Health Administration at the University of Saint Francis (USF), Joliet, Illinois. He teaches both graduate and undergraduate classes in finance and economics. Prior to joining USF he held faculty positions at Illinois Valley Community College, the University of Illinois-Chicago and Governors State University. David was awarded numerous teaching awards during his academic career. Prior to earning his Doctorate in Business Administration he received a MA degree in economics and a BA degree in Finance from the University of South Florida in Tampa. He is currently a member of the American Economic Association, the International Financial Management Association, the National Association of Forensic Economics, the History of Economics Society, the Southern Economics Association and the Southern Finance Association. His research interest includes public finance, labor economics and forensic economics. He has published articles in various business and economics journals. E-mail: dgordon@stfrancis.edu 


\section{REFERENCES}

1. Campbell, Colin D. and Rosemary G. Campbell, An Introduction to Money and Banking, $5^{\text {th }}$ Ed., Dryden Press, New York, NY, 1984.

2. Cecchetti, Stephen G., Money, Banking and Financial Markets, $2^{\text {nd }}$ Ed., McGraw-Hill, New York, NY, 2008.

3. Keat, Paul G. and Philip K. Y. Young (2009). Managerial Economics, $6^{\text {th }}$ edition. Upper Saddle River, New Jersey: Pearson Prentice Hall.

4. Landsburg, Steven E. (2011). Price Theory and Applications, $8^{\text {th }}$ edition. Mason, Ohio: South-Western Cengage.

5. Samuelson, Paul A. (1947). Foundations of Economic Analysis. Cambridge: Cambridge University Press.

6. Silberberg, Eugene and Wing Suen (2001). The Structure of Economics, $3^{\text {rd }}$ edition. New York: McGrawHill.

7. Thomas, Christopher R. and S. Charles Maurice (2011). Managerial Economics, $10^{\text {th }}$ edition. New York: McGraw-Hill. 